\title{
Pulmonary involvement with cytomegalovirus infections in children
}

\author{
S. D. SMITH, C. T. CHO, N. BRAHMACUPTA, AND M. F. LENAHAN
}

From the Departments of Pediatrics, Microbiology and Pathology, University of Kansas Medical Center, College of Health Sciences and Hospital, Kansas City, Kansas, USA

SUMMARY Among 40 hospitalized infants and children with cytomegalovirus infection, 14 (35\%) had interstitial pneumonitis, $4(10 \%)$ had wheezing or tachypnoea but without $x$-ray evidence of classical interstitial pneumonia, the remaining $22(55 \%)$ were free of pulmonary involvement. Most patients had tachypnoea and nonproductive cough of varying durations: those with underlying pulmonary pathology tended to have persistent and prolonged respiratory symptoms. Mortality and severity of the lung disease were related to the underlying immunodeficiency or concomitant pulmonary process.

Clinical presentations of cytomegalovirus (CMV) infection encompass a broad spectrum of symptoms and signs ranging from asymptomatic disease to lethal congenital infection (Hanshaw et al., 1965; Starr and Gold, 1968). The most common features of congenital infection include hepatosplenomegaly, jaundice, petechiae, low birthweight, and microcephaly (Overall and Glasgow, 1970). Acquired CMV infections are often seen in patients with altered host resistance (Hill et al., 1964; Cangir and Sullivan, 1966; Sutton et al., 1967; Neiman et al., 1973), but these infections may also occur in normal hosts (Klemola et al., 1969; Jordan et al., 1973). Various manifestations of acquired CMV infection have been reported, e.g. infectious mononucleosis-like syndrome, hepatitis, postperfusion syndrome, etc. (Hanshaw et al., 1965; Embil et al., 1968; Klemola et al., 1969, 1972; Jordan et al., 1973).

Pneumonia occurs not infrequently in patients dying from CMV infection both in congenital disease (Medearis, 1964; McCracken et al., 1969) and in hosts with altered immunity (Hill et al., 1964; Rifkind et al., 1967). However, the relative incidence and clinical course of pneumonia associated with CMV infection in living human hosts have not been well delineated. Follow-up studies of CMV pulmonary pathology are also lacking. This report describes our experiences concerning the clinical and virological aspects of pulmonary involvement with CMV infection in children.

Received 24 September 1976

\section{Materials and methods}

Eighteen cases of CMV infection with pulmonary involvement were studied. All 18 were children under 15 years of age seen between 1 October 1967 and 31 December 1974 at the University of Kansas Medical Center. All patients had positive CMV isolation and clinical evidence of pulmonary involvement, namely $x$-ray findings of interstitial pneumonitis and/or clinical symptoms involving respiratory system, such as tachypnoea, wheezing, and cough. A group of 22 children with positive CMV isolation but without pulmonary involvement evaluated during the same period were also included for comparison.

Clinical specimens (e.g. urine, throat swabs, tears, saliva, stool, blood, bone marrow, or tissues) were submitted for virus isolation. In most cases blood samples were also collected for antibody studies. To avoid the loss of infectivity of the virus, attempts were made to collect specimens during working hours. The specimens were processed with a minimum of delay after collection and none of the specimens were frozen. All specimens were inoculated into roller tube cultures of embryonic human lung fibroblasts. In addition, specimens were inoculated into HeLa cells, Hep-2 cells, and primary rhesus monkey kidney cells. The cells were examined and maintained for a minimum of 4 weeks by changing the media or by subculture. CMV was isolated and identified by the characteristic focal cytopathic effect (CPE) in the cultured cells of embryonic human lung fibroblast and no CPE in other cell cultures. Confirmation was 
done by subculture, and by indirect immunofluorescent staining using specific CMV antisera in some cases.

Tracheal or lung aspirates were also cultured for bacteria and fungi in 18 patients who had CMV pulmonary involvement. Efforts were also made on every patient to identify the underlying disease or immunodeficiency state. In some patients tissues from lung biopsy or necropsy were obtained for histopathological studies and for isolation and identification of the microbial agents. Follow-up studies include recording of symptoms and signs, chest $x$-ray, and viral studies. Pulmonary function studies were not carried out.

\section{Results}

Interstitial pneumonitis. Among 18 children who had CMV infection with pulmonary involvement, 14 had interstitial pneumonitis, and 4 had respiratory symptoms but without classical radiographic evidence of interstitial pneumonitis. The clinical and laboratory features of 14 patients with interstitial pneumonitis are summarized in Table 1.12 of the 14 patients were under 2 years of age, and the remaining 2 were 7 and 9. There were 8 males and 6 females. Most were beyond the newborn period at the time of diagnosis. Only one infant (Case 1) presented with classical congenital cytomegalic inclusion disease. Other patients, without obvious underlying disease which altered the host defence mechanisms, could also have had congenital CMV infection. The initial clinical presentation of these patients were variable: hepatomegaly (Cases 11,12$)$, pneumonia (Case 6), failure to thrive (Case 4), fever and cough (Case 3), and sudden infant death syndrome (Case 7). 3 infants, aged 2 weeks to $6 \frac{1}{2}$ months, had associated pulmonary pathology, namely pulmonary haemosiderosis (Case 2), respiratory distress syndrome of the newborn followed by bronchopulmonary dysplasia (Case 10), and Haemophilus influenzae empyema (Case 9). Other diagnoses included acute lymphocytic leukaemia (Case 13), Wiskott-Aldrich syndrome (Case 8),

Table 1 Interstitial pneumonitis associated with $C M V$ infection

\begin{tabular}{|c|c|c|c|c|c|c|c|c|}
\hline \multirow[t]{2}{*}{ Case no. } & \multirow[t]{2}{*}{ Age of onset } & \multirow[t]{2}{*}{ Sex } & \multicolumn{2}{|c|}{ Pneumonitis* } & \multicolumn{2}{|c|}{ Virus excretion } & \multirow{2}{*}{$\begin{array}{l}\text { Associated } \\
\text { condition }\end{array}$} & \multirow[t]{2}{*}{ Outcome } \\
\hline & & & Severity & Duration & Sourcet & Duration & & \\
\hline 1 & $1 d$ & $\mathbf{M}$ & ++ & $4 w$ & $\mathrm{U}, \mathrm{T}$ & $>13 \mathrm{~m}$ & $\begin{array}{l}\text { Malnourished } \\
\text { infant }\end{array}$ & Well \\
\hline 2 & $2 w$ & $\mathbf{M}$ & ++ & $24 \mathrm{~m}$ & $\mathbf{U}$ & $3 \mathrm{~m}$ & $\begin{array}{l}\text { Pulmonary } \\
\text { haemosiderosis }\end{array}$ & Died at 3 yr \\
\hline 3 & $6 \mathrm{w}$ & $\mathbf{F}$ & + & $2 w$ & $\mathbf{U}$ & $?$ & $\begin{array}{l}\text { Fever and } \\
\text { cough }\end{array}$ & Well \\
\hline 4 & $6 \mathrm{w}$ & $\mathbf{F}$ & ++ & $5 w$ & $\mathbf{U , T}$ & $>18 \mathrm{~m}$ & $\begin{array}{l}\text { Failure } \\
\text { to thrive }\end{array}$ & Well \\
\hline 5 & $7 w$ & $\mathbf{M}$ & +++ & $1 \mathrm{w}$ & $\mathrm{U}, \mathrm{T}$ & $1 \mathrm{w}$ & $\begin{array}{l}\text { Hypo- } \gamma- \\
\text { globulinae- } \\
\text { mia }\end{array}$ & $\begin{array}{c}\text { Died at } \\
10 \mathrm{w}\end{array}$ \\
\hline 6 & $3 \mathrm{~m}$ & $\mathbf{M}$ & +++ & Persistent & $\mathbf{U}, \mathbf{T}$ & $>15 \mathrm{~m}$ & $\begin{array}{l}\text { Pneumocystis } \\
\quad \text { carinii } \\
\text { pneumonia }\end{array}$ & Well \\
\hline 7 & $3 \mathrm{~m}$ & $\mathbf{F}$ & $?$ & $?$ & Lung & $?$ & $\begin{array}{l}\text { Sudden infant } \\
\text { death }\end{array}$ & Died \\
\hline 8 & $5 \mathrm{~m}$ & $\mathbf{M}$ & +++ & $3 \mathrm{~m}$ & $\mathrm{U}, \mathrm{T}$ & $15 \mathrm{~m}$ & $\begin{array}{l}\text { Wiskott- } \\
\text { Aldrich } \\
\text { syndrome }\end{array}$ & $\begin{array}{l}\text { Died at } \\
20 \mathrm{~m}\end{array}$ \\
\hline 9 & $6 \mathrm{~m}$ & $\mathbf{F}$ & +++ & $8 w$ & $\mathbf{U}, \mathbf{T}$ & $?$ & $\begin{array}{c}\text { Haemophilus } \\
\text { influenzae } \\
\text { empyema }\end{array}$ & Well \\
\hline 10 & $6 \mathrm{~m}$ & $F$ & +++ & Persistent & U,T & $>33 \mathrm{~m}$ & $\begin{array}{l}\text { Broncho- } \\
\text { pulmonary } \\
\text { dysplasia }\end{array}$ & $\begin{array}{l}\text { Recurrent } \\
\text { pneumo- } \\
\text { nia }\end{array}$ \\
\hline $\begin{array}{l}11 \\
12\end{array}$ & $\begin{array}{l}18 \mathrm{~m} \\
18 \mathrm{~m}\end{array}$ & $\begin{array}{l}\mathbf{M} \\
\mathbf{M}\end{array}$ & $\begin{array}{l}++ \\
+++\end{array}$ & $\stackrel{?}{\text { Persistent }}$ & $\begin{array}{l}\mathbf{U} \\
\mathbf{U}, \mathbf{T}\end{array}$ & $\stackrel{?}{>37 \mathrm{~m}}$ & $\begin{array}{l}\text { Hepatomegaly } \\
\text { Hepatospleno- } \\
\text { megaly }\end{array}$ & $\begin{array}{l}\text { Well } \\
\text { Chronic } \\
\text { pneumo- } \\
\text { nia }\end{array}$ \\
\hline 13 & $7 \mathrm{yr}$ & $\mathbf{M}$ & ++ & $9 \mathrm{w}$ & Lung & $?$ & $\begin{array}{l}\text { Acute leukae- } \\
\text { mia }\end{array}$ & Died at 7 yr \\
\hline 14 & $9 \mathrm{yr}$ & $\mathbf{F}$ & +++ & $4 w$ & $\mathbf{U}$ & $?$ & $\begin{array}{l}\text { Post-perfusion } \\
\text { syndrome }\end{array}$ & Well \\
\hline
\end{tabular}

*Severity of pneumonia as determined by $x$-ray changes: $+++=$ severe

(all 5 lobes of the lungs are involved), $++=$ moderate, $+=$ mild

$+U=$ urine, $T=$ throat swabs 
hypo- $\gamma$-globulinaemia (Case 5), and post-perfusion syndrome following surgery for tetralogy of Fallot (Case 14).

Clinical manifestations of interstitial pneumonitis among our patients were relatively mild. Most patients had tachypnoea and nonproductive cough of varying duration. 7 patients had respiratory symptoms of less than 4 weeks. Patients with underlying pulmonary pathology tended to have persistent and prolonged respiratory symptoms. One child (Case 12) has had respiratory symptoms for more than 37 months and has developed clubbing of the fingers.

The $x$-ray findings of patients with pneumonitis are shown in Figs. 1-3. 8 of the 14 patients had diffuse interstitial pneumonitis involving all five lobes of the lung tissues; 6 patients had a lesser degree of involvement. Most of the $x$-ray evidence of pneumonia resolved in less than 8 weeks; however, 4 patients had persistent changes. The histopathological features of CMV pneumonitis consisted of multifocal areas of septal thickening with increased number of histiocytes, lymphocytes, and a few polymorphonuclear leucocytes (Figs. 4, 5). Evidence of hyperplasia of the thymus, lymph nodes, and spleen were seen in a few cases at necropsy.

Pulmonary involvement without $x$-ray evidence of interstitial pneumonia. 4 patients with CMV infection who had respiratory symptoms but without $x$-ray evidence of classical interstitial pneumonitis are summarized in Table 2. Initial diagnosis of these

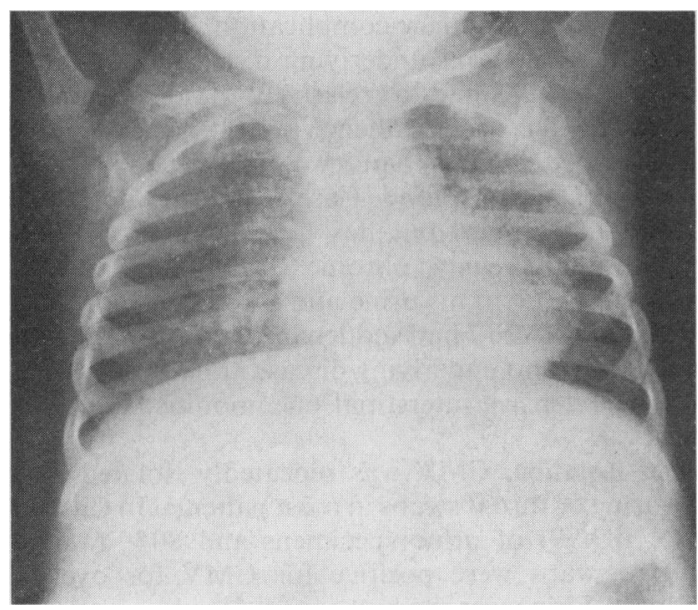

Fig. 1 Case 8. Chest x-ray of CMV interstitial pneumonitis in a child aged 8 months with the WiskottAldrich syndrome. Lung sections at necropsy showed interstitial pneumonitis.

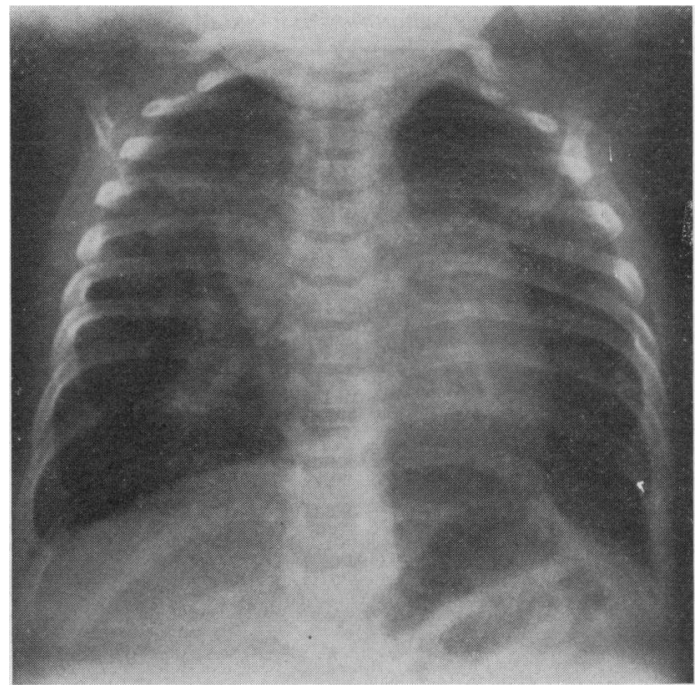

Fig. 2 Case 6. Chest $\mathrm{x}$-ray in a 3-month-old child with a persistent respiratory problem since 3 months of age. Biopsy of the lung showed interstitial pneumonitis and fibrosis. The child had double infection with $C M V$ and Pneumocystis carinii (see Fig. 5).

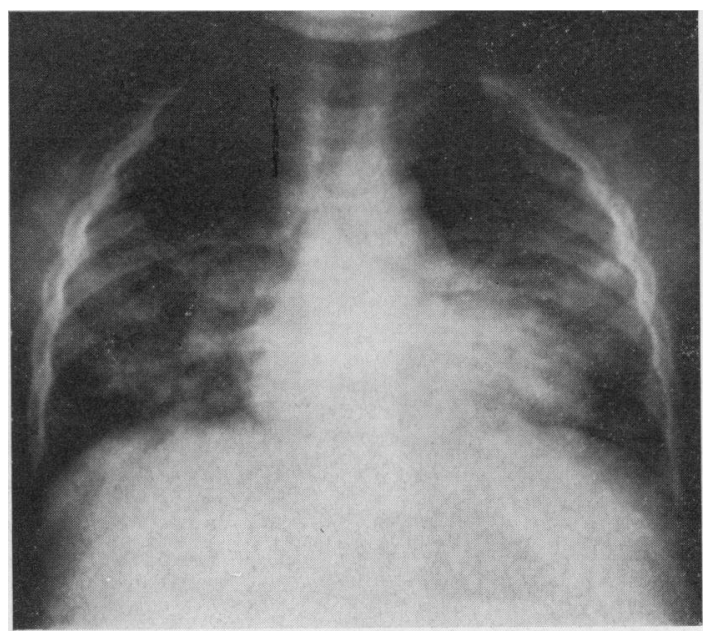

Fig. 3 Case 12. Chest $\mathrm{x}$-ray of interstitial pneumonitis in a 18-month-old child who had no underlying disease except CMV infection. Follow-up for 3 years showed abnormal x-ray.

4 children included agranulocytosis (Case 15), asthma (Case 16), malabsorption (Case 17), and congestive heart failure (Case 18). None of these patients had classical features of congenital cytomegalic inclusion disease. The respiratory symptoms of these children were related to bronchiolitis, 
Table 2 Pulmonary symptoms associated with CMV infection

\begin{tabular}{|c|c|c|c|c|c|c|c|c|}
\hline \multirow[t]{2}{*}{ Case no. } & \multirow[t]{2}{*}{ Age } & \multirow[t]{2}{*}{ Sex } & \multirow[t]{2}{*}{ Chief complaint } & \multirow[t]{2}{*}{ Chest $\mathrm{x}$-ray } & \multirow[t]{2}{*}{ Diagnosis } & \multirow{2}{*}{$\begin{array}{l}\text { Associated } \\
\text { problems }\end{array}$} & \multicolumn{2}{|c|}{$C M V$ isolation } \\
\hline & & & & & & & Urine & Throat \\
\hline 15 & $5 \mathrm{~m}$ & $\mathbf{M}$ & Wheezing & Air trapping & $\begin{array}{l}\text { Bronchio- } \\
\text { litis }\end{array}$ & $\begin{array}{l}\text { Agranulo- } \\
\text { cytosis }\end{array}$ & + & + \\
\hline 16 & $20 \mathrm{~m}$ & $\mathbf{F}$ & Wheezing & Air trapping & $\begin{array}{l}\text { Broncho- } \\
\text { spasm }\end{array}$ & Asthma & ND & + \\
\hline 17 & $3 \mathrm{~m}$ & $\mathbf{F}$ & Tachypnoea & $\begin{array}{l}\text { Consolida- } \\
\text { tion }\end{array}$ & $\begin{array}{l}\text { Lobar } \\
\text { pneumonia } \\
\text { and atelec- } \\
\text { tasis }\end{array}$ & $\begin{array}{l}\text { Malabsorp- } \\
\text { tion }\end{array}$ & + & + \\
\hline 18 & $1 \mathrm{w}$ & $\mathbf{M}$ & $\begin{array}{l}\text { Respiratory } \\
\text { distress }\end{array}$ & $\begin{array}{l}\text { Increased } \\
\text { lung } \\
\text { marking }\end{array}$ & $\begin{array}{l}\text { Congestive } \\
\text { heart } \\
\text { failure }\end{array}$ & $\begin{array}{l}\text { Persistent } \\
\text { fetal } \\
\text { circulation }\end{array}$ & + & + \\
\hline
\end{tabular}

ND = not done.

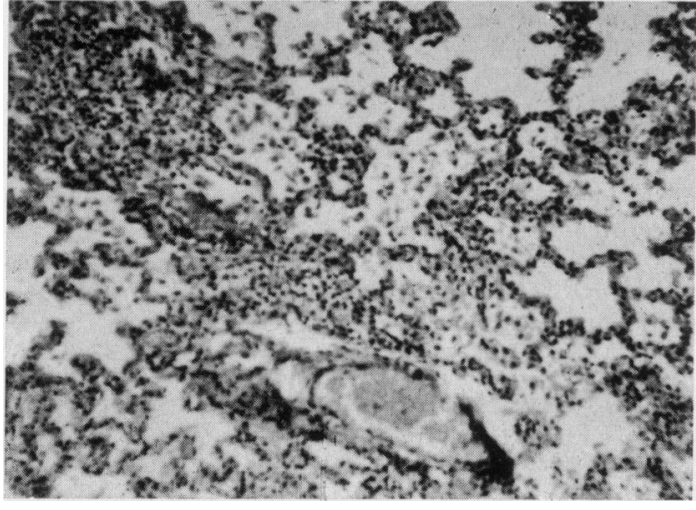

Fig. 4 Case 7. Lung section of a 3-month-old infant with sudden infant death syndrome. $C M V$ was isolated from the lung tissues. $(\times 230$.)

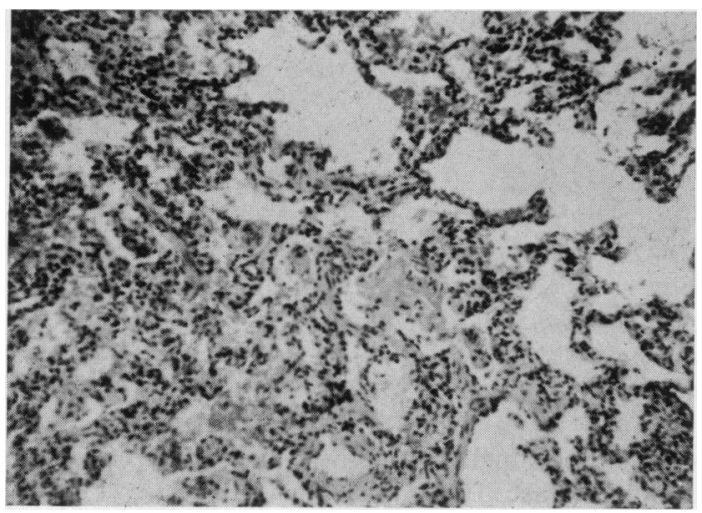

Fig. 5 Case 6. Lung section of a 3-month-old child who had both CMV and Pneumocystis carinii infections involving the lungs. $(\times 230$.) asthma, probable aspiration pneumonia, and congestive heart failure. All 4 patients had wheezing or tachypnoea of less than one week duration. Chest $x$-rays of these patients showed air trapping, increased lung marking, or consolidation. Except for CMV no other viral or bacterial pathogens were isolated from these patients. In addition to the recovery of CMV from the urine specimens, all 4 patients had positive isolation of CMV from the throat swabs.

Course and outcome of pulmonary involvement. The clinical course and prognosis of pulmonary involvement with CMV were variable. 3 patients (Cases 5, 8 , 13) who had underlying immune disorders or leukaemia died of pulmonary complications within 3 months. 3 patients (Cases 2,6,10), who had coexisting pulmonary pathology, developed persistent pneumonia or pulmonary fibrosis; one of these (Case 2) died of the pulmonary complication. The remaining 12 patients without underlying disease all, except 2 (Cases 7, 12), had a relatively mild respiratory symptom. The $x$-ray evidence of pulmonary involvement resolved in less than 8 weeks. The prognosis for these patients was good. Case 12 had no detectable underlying disease but has had persistent massive hepatosplenomegaly, chronic pneumonia, and has excreted CMV in his urine and throat for more than 37 months. Case 7 had sudden infant death syndrome and showed no underlying disease at necropsy except for the extensive interstitial pneumonitis (Fig. 4).

Virus isolation. CMV was repeatedly isolated from the urine or throat swabs in most patients. In Case 12, $90 \%(89 / 99)$ of urine specimens and $80 \%(4 / 5)$ of throat swabs were positive for CMV for over 37 months. Urine was the best source for virus isolation. Among 36 patients from whom urines were submitted for culture, all except one had CMV isolated. Follow-up of urine culture for CMV indicated that several of these children continued to excrete CMV 
for over one year (Table 1). Excretion of CMV from the upper respiratory tract appeared to correlate with the presence or absence of pulmonary involvement (Table 3). The rates of CMV recovery from throat swabs were $92 \%(13 / 14)$ in children with pulmonary involvement and $22 \%(2 / 9)$ in children without. The virus was recovered from 2 patients (Cases 7, 13) in the lung tissues at necropsy.

Table 3 Characteristics of CMV infection among children with or without pulmonary involvement

\begin{tabular}{lll}
\hline Features & $\begin{array}{c}\text { With pulmonary } \\
\text { involvement } \\
(18 \text { patients })\end{array}$ & $\begin{array}{c}\text { Without pulmonary } \\
\text { involvement } \\
(22 \text { patients })\end{array}$ \\
\hline Virus isolation & $\begin{array}{c}100 \%(15 / 15) \text { in } \\
\text { urine } \\
92 \%(13 / 14) \text { in } \\
\text { throat }\end{array}$ & $\begin{array}{c}95 \%(21 / 22) \text { in } \\
\text { urine } \\
22 \%(2 / 9) \text { in throat }\end{array}$ \\
$\begin{array}{c}\text { Underlying immune } \\
\text { disorders }\end{array}$ & $16 \%(3)$ & $0 \%(0)$ \\
$\begin{array}{c}\text { Death associated } \\
\text { with pulmonary } \\
\text { failure }\end{array}$ & $28 \%(5)$ & $0 \%(0)$ \\
Hepatomegaly & $88 \%(16)$ & $54 \%(12)$ \\
\hline
\end{tabular}

No. in parentheses represents number of patients. In some patients only one specimen (urine, throat swab, or lung tissues) was submitted for virus isolation. Some patients had positive CMV isolation in the urine and negative in the throat swab or vice versa.

Patients without pulmonary involvement. Of 22 children with $\mathrm{CMV}$ infection but no respiratory complaints, none had malignancies or diseases which altered host resistance. The primary reasons for evaluating these patients were developmental delay (6), unexplained hepatomegaly (4), seizures (4), congenital heart disease (3), haematuria (2), thrombocytopenia (1), periorbital oedema (1), and diarrhoea (1).

The characteristics of children with and without pulmonary involvement in CMV infection are summarized in Table 3. Patients with pulmonary manifestations more often had underlying immunodeficiency or lung pathology. Furthermore, the incidence of hepatomegaly was higher, and other systemic manifestations were also more common in these patients. The mortality rate was $28 \%$ in those with pulmonary involvement; none of the 22 patients without pulmonary symptoms died.

\section{Discussion}

Pulmonary findings associated with CMV infection may be manifested as interstitial pneumonitis or other nonspecific symptoms (e.g. bronchiolitis, asthma, respiratory distress of the newborn, or atelectasis). Interstitial pneumonitis of varying severity is the most common manifestation. Our findings have confirmed and extended the earlier reports of pneumonia with CMV infection (Hill et al., 1964; Medearis, 1964; Rifkind et al., 1967; McCracken et al., 1969; Klemola et al., 1972). Documentation of CMV infection and pulmonary involvement was made by isolation of the virus and by histopathological changes from lung biopsy or necropsy in some cases. In the majority of the cases the diagnosis was made by clinical and $x$-ray findings. The high incidence $(92 \%)$ of CMV recovery from throat swabs of patients with pulmonary complaints and low $(22 \%)$ recovery from patients with no pulmonary symptoms provide further indirect evidence of the association of CMV and the pulmonary pathology, though this association is not well defined. In an earlier report (McCracken et al., 1969) it was found that pneumonia occurred in approximately $25 \%$ of infants with congenital cytomegalic inclusion disease. Among 40 children with CMV infection in our series, $14(35 \%)$ had interstitial pneumonitis, $4(10 \%)$ had respiratory symptoms without $x$-ray evidence of interstitial pneumonia, and the remaining $22(55 \%)$ were free of pulmonary involvement. (Our cases were selected from hospitalized infants and children who presented with clinical features compatible with CMV infection or other diagnositic problems.)

Host factors seem to play an important role in the clinical course of pulmonary pathology in CMV infection. The mortality and prognosis of pulmonary disease with CMV were related to the underlying disease. The respiratory symptoms observed in patients without underlying disease were relatively mild and were self limited. On the other hand, pulmonary involvement of CMV infection in immunologically suppressed patients had a poor prognosis and patients frequently died of the respiratory complications. The grave consequences of lung involvement of CMV infection in these patients have been well recognized (Cangir and Sullivan, 1966; Rifkind et al., 1967; Neiman et al., 1973). Additionally, CMV infection was seen in a group of patients who had normal immunological functions but had suffered a significant pulmonary insult during the newborn period or had an associated chronic respiratory problem. These patients tended to have a protracted clinical course of respiratory symptoms and persistent $x$-ray changes suggestive of pulmonary fibrosis. The role of CMV in these processes is difficult to determine: damage to the local defence mechanisms in the lungs may have contributed to the persistent infection and delayed resolution of the infiltrates. 


\section{References}

Cangir, A., and Sullivan, M. P. (1966). The occurrence of cytomegalovirus infection in childhood leukemia: report of three cases. Journal of the American Medical Association, 195, 616-622.

Embil, J. A., Folkins, D. F., Haldane, E. V., and Van Rooyen, C. E. (1968). Cytomegalovirus infection following extracorporeal circulation in children. A prospective study. Lancet, 2, 1151-1155.

Hanshaw, J. B., Betts, R. F., Simon, G., and Boynton, R. C. (1965). Acquired cytomegalovirus infection. Association with hepatomegaly and abnormal liver-function tests. New England Journal of Medicine, 272, 602-609.

Hill, R. B., Jr., Rowlands, D. T., Jr., and Rifkind, D. (1964). Infectious pulmonary disease in patients receiving immunosuppressive therapy for organ transplantation. New England Journal of Medicine, 271, 1021-1027.

Jordon, M. C., Rousseau, W. E., Stewart, J. A., Noble, G. R., and Chin, T. D. (1973). Spontaneous cytomegalovirus mononucleosis. Annals of Internal Medicine, 79, 153-160.

Klemola, E., Von Essen, R., Wager, O., Haltia, K. Koivuniemi, A., and Salmi, I. (1969). Cytomegalovirus mononucleosis in previously healthy individuals. Five new cases and follow-up of 13 previously published cases. Annals of Internal Medicine, 71, 11-19.

Klemola, E., Stenström, R., and von Essen, R. (1972). Pneumonia as a clinical manifestation of cytomegalovirus infection in previously healthy adults. Scandinavian Journal of Infectious Disease, 4, 7-10.
McCracken, G. H., Shinefield, H. R., Cobb, K., Rausen, A. R., Dische, M. R., and Eichenwald, H. F. (1969). Congenital cytomegalic inclusion disease. American Journal of Diseases of Children, 117, 522-539.

Medearis, D. N., Jr. (1964). Observations concerning human cytomegalovirus infection and disease. Bulletin of the Johns Hopkins Hospital, 114, 181-211.

Neiman, P., Wasserman, P. B., Wentworth, B. B., Kao, G. F., Lerner, K. G., Storb, K. G., Storb, R., Buckner, C. D. Clift, R. A., Fefer, H., Fass, L., Glucksberg, H., and Thomas, E. D. (1973). Interstitial pneumonitis and cytomegalovirus infection as complications of human marrow transplantations. Transplantation, 15, 478-485.

Overall, J. C., and Glasgow, L. A. (1970). Virus infections of the fetus and newborn infant. Journal of Pediatrics, 77, 315-333.

Rifkind, D., Goodman, N., and Hill, R. B., Jr. (1967). The clinical significance of cytomegalovirus infection in renal transplant recipients. Annals of Internal Medicine, 66, 1116-1128.

Starr, J. G., and Gold, E. (1968). Screening of newborn infants for cytomegalovirus infections. Journal of Pediatrics, 73, 820-824.

Sutton, R. N. P., Darky, C. W., and Gumpel, S. M. (1967). CMV infection in childhood leukaemia. British Journal of Haematology, 20, 437-442.

Correspondence to Dr C. T. Cho, Department of Pediatrics, University of Kansas Medical Center, 39th and Rainbow Blvd., Kansas City, Kansas 66103, USA. 